\title{
KONSEP ASUHAN KEPERAWATAN PADA ANAK DENGAN GANGGUAN BAHASA DAN BICARA DI SLB-AB BUKESRA BANDA ACEH
}

\author{
*Yulsafli, **Fitri Irfani \\ *Yulsafli adalah Dosen FKIP Universitas Serambi Mekkah Banda Aceh \\ Email: yulsafli@serambimekkah.ac.id \\ **Fitri Irfani adalah dosen FKIP Universitas Serambi Mekkah \\ Email : yulsafli@serambimekkah.ac.id
}

\begin{abstract}
Abstrak
Penelitian ini berjudul "Konsep Asuhan Keperawatan Pada Anak Dengan Gangguan Bahasa dan Bicara di SLB-AB BUKESRA Banda Aceh". Adapun yang menjadi tujuan penelitian adalah untuk mengetahui konsep asuhan keperawatan pada anak dengan gangguan bahasa dan bicara. Jenis penelitian yang digunakan adalah penelitian kualitatif,.Teknik pegumpulan data yang digunakan dalam penelitian ini adalah teknik observasi dan wawancara. Teknik analisis data yang digunakan dalam penelitian ini adalah deskriptif Kualitatif, data-data yang terkumpul direduksi dan menyusun berbagai katagori sesuai dengan tema dan tujuan penelitian, sehingga dapat menjawah permasalahan penelitian. Adapun yang menjadi hasil penelitian ini adalah pada umumnya, untuk anak yang normal dengan kita berbicara memakai bahasa sehari-hari, anak normal dapat mengerti, sedangkan untuk anak dengan gangguan bahasa dan bicara, kita harus mengeja apa yang ingin kita katakan padanya, juga kita harus menggunakan bahasa tubuh, agar ucapan kita dapat dimengerti olehnya, apabila tidak dimengerti juga, kami harus mengeja dan mengulangnya kembali. Yang pasti asuhannya berbeda dengan anak yang normal.
\end{abstract}

Kata kunci: Konsep Asuhan, Keperawatan, Bahasa, Bicara

\section{PENDAHULUAN}

Keperawatan adalah suatu profesi yang memberikan bantuan pada individu dan kelompok untuk mencapai, memelihara dan mempertahankan derajat kesehatan dengan memperhatikan, memikirkan, menghubungkan, menentukan dan melakukan tindakan keperawatan sehingga individu dan kelompok berperilaku yang sesuai dengan kondisi keperawatan. Keperawatan berhubungan langsung dengan lingkungan, tempat atau ruang dan waktu untuk membentuk suatu hubungan menanggulangi status kesehatan dalam proses interversonal reaksi interaksi dan transaksi dimana perawat dank lien berbagi informasi mengenai persepsinya dalam keperawatan. Kerangka ini dikenal dengan sistem kerangka terbuka. Asumsi yang mendasari kerangka ini adalah asuhan keperawatan berfokus kepada manusia termasuk berbagai hal yang mempengaruhi keperawatan seseorang.

Jurnal Serambi IImu. p-ISSN 1693-4849, e-ISSN 2549-2306 
Keperawatan terutama berfungsi membantu individu (sehat atau sakit) dan menjalankan kegiatan yang mengkonstribusi kesehatan atau pemulihan (kematian secara damai) yang dapat mereka lakukan tanpa bantuan apabila mereka memiliki kekuatan, kemauan atau pengetahuan yang diperlukan. Keperawatan juga membantu individu melaksanakan terapi yang disarankan dan secepat mungkin mandiri kembali.

Perawat profesional adalah perawat yang mengikuti pendidikan keperawatan pada jenjang pendidikan tinggi keperawatan, sekurang-kurangnya DIII keperawatan. Perawat profesional bertanggung jawab dan berwenang memberikan pelayanan keperawatan secara mandiri atau berkolaborasi dengan tenaga kesehatan lain sesuai dengan kewenangannya.

Dalam menyelenggarakna pelayanan keperawatan, perhatian utama seorang perawat adalah mempelajari bentuk dan sebab tidak terpenuhinya kebutuhan dasar manusia melalui pengkajian yang seksama tentang hal-hal yang melatar belakangi, serta mempelajari berbagai bentuk upaya untuk memenuhi kebutuhan dasar tersebut melalui pemanfaatan berbgai sumber yang tersedi, konsorsium imlu-ilmu kesehatan.

Komunikasi adalah proses berbagai makna melalui perilaku verbal dan nonverbal. Segala perilaku dapat disebut komunikasi jika melibatkan dua orang atau lebih. Komunikasi terjadi jika setidaknya suatu sumber membangkitkan respons pada penerima melalui penyampaian suatu pesan dalam bentuk tanda atau simbol, baik bentuk verbal (kata-kata) maupun nonverbal (tidak dengan kata-kata), tanpa harus memastikan terlebih dahulu bahwa kedua pihak yang berkomunikasi punya suatu sistem simbol yang sama (Mulyana, 2005:3).

Manusia berinteraksi satu dengan yang lain melalui komunikasi dalam bentuk bahasa. Komunikasi tersebut terjadi baik secara verbal maupun non verbal yaitu dengan tulisan, bacaan dan tanda atau simbol. Berbahasa itu sendiri merupakan proses kompleks yang tidak terjadi begitu saja. Manusia berkomunikasi lewat bahasa memerlukan proses yang berkembang dalam tahap-tahap usianya. Bagaimana manusia bisa menggunakan bahasa sebagai cara berkomunikasi selalu menjadi pertanyaa yang menarik untuk dibahas sehingga memunculkan banyak teori tentang pemerolehan bahasa.

Beberpa peneliti mengungkapkan bahwa keterlambatan berbicara sering dikaitkan dengan gangguan perkembangan, gangguan perilaku, gangguan motorik oral dan gangguan fungsi motorik lainnya. Bila berbagai gangguan yang terjadi hampir bersamaan tersebut tidak disikapi dengan baik, maka akan menganggu tumbuh dan berkembangnya anak di masa

Jurnal Serambi IImu. p-ISSN 1693-4849, e-ISSN 2549-2306 Journal of Scientific Information and Educational Creativity 
depan. Kemampuan berbahasa juga membedakan manusia dengan binatang. Orangtua dengan antusias menunggu awal perkembangan bicara pada anak mereka. Bila anak tidak dapat bicara normal, maka mereka mengira bahwa anak mereka bodoh atau retardasi. Sering orangtua memperkirakan bahwa perkembangan bicara anak diluar normal merupakan suatu hal yang mengkhawatirkan, sehingga membawanya ke dokter.

Kemampuan bahasa merupakan indikator seluruh perkembangan anak. Karena kemampuan berbahasa sensitif terhadap keterlambatan atau kerusakan pada sistem lainnya, sebab melibatkan kemampuan kognotif, sensorik motor, psikologis, emosi, dan lingkungan disekitar anak. Seorang anak tidak akan mampu berbicara dengan dukungan dari lingkungannya. Mereka harus mendengar pembicaraan yang berkaitan dengan kehidupannya sehari-hari maupun pengetahuan tentang dunia. Mereka harus belajar mengekspresikan dirinya, membagi pengalamannya dengan orang lain dan mengemukakan keinginannya.

Gangguan bicara merupakan salah satu masalah yang sering terdapat pada anakanak. Menurut NCHS, berdasarkan atas laporan orangtua (diluar gangguan pendengaran serta celah pada palatum), maka angka kejadiannya adalah $0,9 \%$ pada anak dibawah umur 5 tahun dan 1,95\% pada anak yang berumur 4-14 tahun. Dari hasil evaluasi langsung terhadap anak usia sekolah, angka kejadiannya 3,8 kali lebih tinggi dari yang berdasarkan hasil wawancara. Berdasarkan hal ini, diperkirakan gangguan bicara dan bahasa pada anak adalah sekitar $4-5 \%$.

Diteksi dini diperlukan, agar penyebabnya dapat segera dicari, sehingga pengobatan serta pemilihannya dapat dilakukan seawal mungkin. Contohnya, pada seorang anak yang tuli konduksi tetapi cerdas yang terdapat mendapat alat bantu dengar dan terapi wicara, serta tidak diberi kesempatan mengembangkan sistem komunikasi non verbal oleh dirinya sendiri sebelum usia 3 tahun, maka kesempatan untuk mengajarinya agar mampu berbicara yang dapat dimengerti, jelas dan terang telah hilang.

Hemisfer kiri merupakan pusat kemampuan berbahasa pada 94\% orang dewasa kanan dan lebih dari $75 \%$ pada orang dewasa kidal. Pengkhususan hemisfer untuk fungsi bahasa sudah dimulai sejak di dalam kandungan, tetapi berfungsi secara sempurna setelah beberapa tahun kemudian. Berbagai penelitian menunjukkan bahwa anak dengan kerusakan otak unilateral sebelum maupun sesudah lahir, diperkirakan fungsi berbahasa dapat 
diprogram oleh hemisfer lainnya, walaupun kelainan yang khusus masih dapat ditemukan dengan tes yang teliti. Kelenturan perkembangan otak anak seperti ini menyebabkan macam perkembangan bahasa pada anak sukar ditentukan.

Keperawatan adalah suatu profesi yang memberikan bantuan pada individu dan kelompok untuk mencapai, memelihara dan mempertahankan derajat kesehatan dengan memperhatikan, memikirkan, dan menghubungkan, menentukan dan melakukan tindakan keperawatan sebagai sehingga individu dan kelompok berperilaku yang sesuai dengan kondisi keperawatan. Keperawatan berhubungan langsung dengan lingkungan, tempat atau ruang dan waktu untuk membentuk hubungan menangguangi status kesehatan dalam proses interpersonal reaksi interaksi dimana perawat dank lien berbagi informasi mengenai persepsinya dalam keperawatan. Kerangka ini dikenal dengan sistem kerangka terbuka. Asumsi yang mendasari kerangka ini adalah asuhan keperawatan berfokus kepada manusia termasuk berbagainhal yang mempengaruhi kesehatan seseorang. Filosofi keperawatan anak merupakan keyakinan atau pandangan yang dimiliki perawat dalam memberikan pelayanan keperawatan pada anak yang berfokus pada keluarga (family centered care), pencegahan terhadap trauma (atraumatic care) dan manjemen kasus (Hidayat,2005:78).

Berbahasa atau bicara adalah alat komunikasi yang ingin disampaikan seseorang untuk mencampaikan tujuan yang ingin dimaksud oleh seseorang tersebut (Tarigan, 1983:65), lain halnya dengan Hastuti (2003: 75-76), mengemukakan bahwa "berbicara adalah mengungkapkan sesuatu yang ada di dalam pikiran untuk di sampaikan kepada orang lain".

Keterampilan berbicara merupakan suatu proses perkembangan. Berbicara memerlukan pengalaman, waktu, dan kesempatan latihan keterampilan-keterampilan khusus. Penuturan Bahasa Indonesia tinggi rendahnya nada suara tidak fungsional atau tidak membedakan makna. Dengan nada tinggi sedang atau rendah maknanya sama saja, berbeda dengan tekanan nada, tekanan nada dalam tutur bahasa Indonesia berfungsi membedakan makna dalam tataran kata (Muslich, 2008:112-113).

Dilihat dari sudut penutur, maka bahasa itu berfungsi personal atau pribadi maksudnya, si penutur menyatakan sikap terhadap apa yang dituturkannya. Si penutur bukan hanya mengungkapkan emosi lewat bahasa, tetapi juga memperlihatkan emosi itu sewaktu

Jurnal Serambi IImu. p-ISSN 1693-4849, e-ISSN 2549-2306 Journal of Scientific Information and Educational Creativity 
menyampaikan tuturnya. Dalam hal ini pihak si pendengar juga dapat menduga apakah si penutur sedih, marah, atau gembira.

Dilihat dari segi pendengaran atau lewat bicara, maka bahasa itu berfungsi direktif, yaitu mengatur tingkah laku pendengar. Di sini bahasa itu tidak hanya membuat si pendengar melakukan sesuatu, tetapi melakukan kegiatan yang sesuai dengan yang dimaui si pembicara. Hal ini dapat dilakukan si penutur dengan menggunakan kalimat-kalimat yang menyatakan perintah, himbauan, permintaan, maupun rayuan.

Bila dilihat dari segi topik ujaran, maka bahasa itu berfungsi representational. Di sini bahasa itu berfungsi sebagai alat untuk membicarakan objek atau peristiwa yang ada disekeliling penutur atau yang ada dalam budaya pada umumnya. Fungsi referensial inilah yang melahirkan paham tradisional bahwa bahasa itu adalah alat untuk menyatakan pikiran, untuk menyatakan bagaimana pendapat si penutur tentang dunia di sekelilingnya.

Kalau dilihat dari segi kode yang digunakan, maka bahasa itu berfungsi metalingual atau metalinguistik yakni bahasa itu digunakan untuk membicarakan bahasa itu sendiri. Memang tampaknya agak aneh, biasanya bahasa itu digunakan untuk membicarakan masalah lain, seperti masalah politik, ekonomi, atau pertanian, tetapi dalam fungsinya disini bahasa itu digunakan untuk membicarakan atau menjelaskan bahasa. Hal ini dapat dilihat dalam proses pembelajaran bahasa di mana kaidah-kaidah atau aturan-aturan bahasa dijelaskan dengan bahasa. Juga dalam kamus monolingual, bahasa itu digunakan untuk menjelaskan arti bahasa (dalam hal ini kata) itu sendiri.

Kalau dilihat dari segi amanat (massage) yang akan disampaikan maka bahasa itu berfungsi imajinasi. Sesungguhnya bahasa itu dapat digunakan untuk menyampaikan pikiran, gagasan, dan perasaan, baik yang sebenarnya, maupun yang Cuma imajinatif (khayalan, rekaan) saja. Fungsi imajinatif ini biasanya berupa karya seni (puisi, cerita, dongeng, lelucon) yang digunakan untuk kesenangan penutur, maupun para pendengarnya.

Jadi dapat disimpulkan keterampilan berbicara adalah kemampuan seseorang dalam berbahasa dengan tujuan menyampaikan maksud yang ingin di capai.

Tujuan utama berbicara adalah untuk berkomunikasi. Komunikasi merupakan pengiriman dan penerimaan pesan atau berita antara dua orang atau lebih sehingga pesan yang dimaksud dapat dipahami. Oleh karena itu, agar dapat menyampaikan pesan secara 
efektif, pembicara harus memahami apa yang akan disampaikan atau dikomunikasikan. Tarigan juga mengemukakan bahwa berbicara mempunyai tiga maksud umum yaitu untuk memberitahukan dan melaporkan (to inform), menjamu dan menghibur (to entertain), serta untuk membujuk, mengajak, mendesak dan meyakinkan (to persuade).

Tim LBB SSC Intersolusi (2006:84) berpendapat bahwa tujuan berbicara ialah untuk: (1) memberitahukan sesuatu kepada pendengar, (2) meyakinkan atau mempengaruhi pendengar, dan (3) menghibur pendengar. Pendapat ini mempunyai maksud yang sama dengan pendapat-pendapat yang telah diuraikan di atas. Berdasarkan beberapa pendapat yang telah dikemukakan di atas, dapat disimpulkan bahwa tujuan berbicara yang utama ialah untuk berkomunikasi. Sedangkan tujuan berbicara secara umum ialah untuk memberitahukan atau melaporkan informasi kepada penerima informasi, meyakinkan atau mempengaruhi penerima informasi, untuk menghibur, serta menghendaki reaksi dari pendengar atau penerima informasi. Adapun kemampuan yang dinilai dalam berbicara adalah sebagai berikut.

1. Lafal dan Intonasi

Lafal adalah suatu cara seseorang atau sekelompok orang dalam mengucapkan bunyi bahasa. Bunyi bahasa Indonesia meliputi Vokal, konsonan, diftone, gabungan konsonan. Intonasi adalah naik turunnya lagu kalimat. Intonasi berfungsi sebagai pembentuk makna kalimat.

\section{Ketepatan susunan kalimat}

Kalimat merupakan primadona dalam kajian bahasa. Hal ini disebabkan antara lain karena dengan perantaraan kalimatlah seorang guru atau dosen dapat menyampaikan maksud secara lengkap dan jelas. Satuan bentuk bahasa yang sudah kita kenal sebelum sampai pada ttaran kalimat adalah frasa atau kelompok kata. Kata dan frasa tidak dapat mengungkapkan suatu maksud secara lengkap dan jelas, kecuali jika kata dan frasa itu sedang berperan dalam kalimat minor atau merupakan jawaban sebuah pernyataan. Untuk dapat berkalimat dengan baik perlu kita pahami terlebih dahulu sturuktur dasar suatu kalimat.

3. Ketepatan pilihan kata

Diksi adalah ketepatan pilihan kata untuk menyatakan sesuatu. Diksi atau pilihan kata pada dasarnya adalah hasil upaya memilih kata tertentu untuk dipakai dalam kalimat,

Jurnal Serambi IImu. p-ISSN 1693-4849, e-ISSN 2549-2306 
alinea, atau wacana. Beberapa fungsi diksi secara umum adalah sebagai berikut 1) Melambangkan gagasan yang diekspresikan secara verbal, 2) Membentuk gaya ekspresi gagasan yang tepat (sangat resmi, tidak resmi) sehingga menyenangkan pendengar atau pembaca, 3) Menciptakan komunikasi yang baik dan benar, 4) Menciptakan suasana yang tepat, 5) Mencegah perbedaan penafsiran, 6) Mencegah salah pemahaman, 7) Mengefektifkan pencapaian target komunikasi.

Pilihan kata hendaknya tepat, jelas dan bervariasi. Jelas maksudnya mudah dimengerti oleh pendengar yang menjadi sasaran, pendengar akan lebih terangsang dan akan lebih paham kalau kata-kata yang digunakan yang sudah dikenal oleh pendengar.

4. Kesesuaian gagasan dengan cerita

Kesesuaian gagasan dengan cerita yaitu sebuah cerita harus sesuai dengan gagasan yang telah ada, sebuah cerita harus ada gagasan agar cerita terebut memiliki suatu arti atau pesan yang dapat ditiru oleh seseorang

5. Kejelasan cerita

Karakteristik cerita anak tidak berbeda halnya dengan hakikat sastra pada umumnya. Menurut Nurgiyantoro (2005:218) pada hakikatnya sastra adalah citra kehidupan, gambaran kehidupan. Selanjutnya menurut pendapat Lukens (2003:8) “Cerita anak adalah cerita yang menceritakan tentang gambar-gambar dan binatang-binatang maupun manusia dengan lingkungan".

Dalam cerita anak tergambar peristiwa kehidupan karakter tokoh dalam menjalani kehidupan sebagaimana diungkapkan dalam alur cerita. Dengan demikian cerita anak adalah subjek yang menjadi fokus perhatian, dan hal itu tercermin secara konkret dalam cerita. Menurut Nurgiyantoro (2005:35) "Cerita anak adalah cerita yang di mana anak merupakan subjek yang menjadi fokus perhatian. Tokoh cerita anak boleh siapa saja, namun mesti ada anak-anaknya, dan tokoh anak itu tidak hanya menjadi pusat perhatian, tetapi juga pusat pengisahan".

6. Kelancaran berbicara pada saat bercerita dongeng

Bicara yang berpusat pada diri sendiri (Egosentrik). Anak berbicara bagi kesempatan diri mereka sendiri atau karena kesenangan berhubungan dengan seseorang yang kebetulan bersamanya. Mereka tidak berusaha untuk bertukar ide atau memperhatikan 
pendapat seseorang. Sedangkan bicara yang berpusat pada orang lain adalah bicara yang disesuaikan dengan bicara atau perilaku seseorang yang diajak bicara. Hal ini terjadi apabila anak mampu mengubah perspektif mental mereka dan mampu memandang situasi dari sudut pandang orang lain ketimbang dari sudut pandang mereka sendiri. Kemudian mereka mampu berkomunikasi dan melibatkan diri dalam pertukaran ide.

Berbicara merupakan aktivitas motorik yang mengandung modalitas psiis. Oleh arena itu, gangguan berbicara ini dapat dikelompokkan kedalam dua kategori. Pertama, gangguan mekanisme berbicara yang berimplikasi pada ganguan organik dan yang ke dua gangguan berbicara psikogenetik.

Area bicara sentral terdiri dari area Broca di lobuis frontal, area Wernicke di lobus temporal, dan serabut-serabut berkas subkortikal yang saling menghubungkan kedua arena itu, fasikulus ar-kuatus. Jaras ini baerkaitan dengan pengulangan kata-kata yang diucapkan. Lesi di bagian dalam area bicara sentral dapat mengakibatkan afasia global. Kelainan ini jarang dan biasanya disebabkan oleh oklusi arteri serebrum tengah tengah yang selanjutnya disertai dengan infark pada sebagian besar hemarfer yang dominan. Penderita memperlihatkan tanda-tanda hilangnya komprehensif bahasa dan kelancaran bicara dan suatu kombinasi afasia reseptif dan ekspresif (disamping defek motorik dan sensorik) (Jack de Groot, 1997:219).

Mekanisme berbicara adalah suatu proses produksi ucapan (perataan) oleh kegiatan terpadu dari pita suara, lidah, otot-otot yang membentuk rongga mulut serta kerongkongan, dan paru-paru. Maka gangguan berbicara berdasarkan mekanismenya ini dapat dirinci menjadi gangguan berbicara akibat kelainan pada paru-paru (pilmonal), pada pita suara (laringan), pada lidah (lingual), dan pada rongga mulut dan kerongkongan (resonantal).

Gangguan Akibat Faktor PulmonalGangguan berbicara ini dialami oleh para penderita penyakit paru-paru. Para penderita penyakit ini kekuatan bernafasnya sangat kurang, sehingga cara berbicaranya diwarnai oleh nada yang monoton, volume suara kecil sekali dan terputus-putus, meskipun dari segi semantik dan sintaksis tidak ada masalah.

Gangguan Akibat Faktor Laringan. Gangguan pada pita suara menyebabkan suara yang dihasilkan menjadi serak atau hilang sama sekali. Gangguan berbicara akibat faktor laringan ini ditandai oleh suara yang serak atau hilang. Tanpa kelainan semantik dan sintaksisnya, artinya dilihat dari segi semantik dan sintaksis ucapannya bisa diterima.

Jurnal Serambi IImu. p-ISSN 1693-4849, e-ISSN 2549-2306 Journal of Scientific Information and Educational Creativity 
Gangguan Akibat Faktor Lingual. Lidah yang sariawan atau terluka akan terasa pedih kalau digerakkan. Untuk mencegah timbulnya rasa pedih ini ketika berbicara maka gerak aktivitas lidah itu dikurangi secara semaunya. Dalam keadaan seperti ini makan pengucapan sejumlah fonem menjadi tida sempurna. Sehingga misalnya, kalimat "sudah barang tentu dia akan menyangkal" mungin akan diucapkan menjadi hu ah ba-ang ke-ku ia a-an me-angay". Pada orang yang terkena strok dan badannya lumbuh sebelah, maka lidahnyapun lumpuh sebelah. Oleh karena itu, cara berbicara juga aan terganggu, yaitu menjadi pelo atau cadel. Istilah medisnya disatria (yang berarti terganggunya artikulasi).

Gangguan Akibat faktor resonansi. Gangguan aibat faktor resonansi ini menyebabkan suara yang dihasilkan menjadi bersengau. Pada orang sumbing. Misalnya, suara menjadi tersengau (bindeng) karena rongga mulut dan rongga hidung yang digunakan untuk berkomunikasi melalui defek di langit-langit keras (palatum), sehingga seronansi yang seharusnya menjadi terganggu. Hal ini juga pada orang yang mengalami kelumpuhan pada langit-langit lunak (velum). Rongga langit-langit ini tidak memberikan resonansi yang seharusnya, sehingga suaranya menjadi tersengau. Penderita penyakit miastenia gravis (gangguan yang menyebaban otot menjadi lemah dan cepat lelah) seing dikenal secara langsung karena kesengauan ini. Gangguan Aibat Multifaktorial.Akibat gangguan multifaktorial atau berbagai faktor menyebaban terjadinya berbagai gangguan berbicara. Antara lain adalah sebagai beriut:

Bebicara Serampangan. Bebicara serampangan atau semberono adalah berbicara dengan cepat sekali, dengan artikulasi yang rusak, ditambah dengan "menelan" sejumlah suku kata, sehingga apa yang diucapkan sukar dipahami. Dalam kehidupan sehari-hari kasusini memang jarang dijumpai tetapi di dalam praktek kedokteran sering ditemui. Umpamanya kalimat "kemarin pagi saya sudah beberapa kali kesini" diucapkan dengan cepat menjadi "kemary sdada berali ksni". Berbicara serampangan ini karena kerusakan di sereblum atau bisa juga terjadi sehabis terkena kelumpuhan ringan sebelah badan.

Berbicara Propulsif. Gangguan berbicara propulsif biasanya terdapat pada para penderita penyakit parkoinson (erusakan pada otak yang menyebabkan otot menjadi gemetar, kaku dan lemah). Para penderita penyakkit ini biasanya bermasalah dalam melakukan gerakan-gerakan. Mereka sukar sekali untuk memulai suatu gerakan. Namun bila 
sudah bergek maka, ia dapat terus menerus tanpa henti. Gerak yang laju terus disebut propulsi. Pada waktu berbicara ciri khas ini akan tampak pula.

Berbicara Mutis (Mutisme). Penderita gangguan mutisme ini tidak berbicara sama sekali. Sebagian besar dari mereka mungkin masih dapat dianggap membisu, yakni memang sengaja tidak mau berbicara. Mutisme ini sebenarnya bukan hanya tidak dapat berkomunikasi secara verbal saja tetapi juga tidak berkomunikasi secara visual maupun isyarat, seperti dengan gerak gerik dan sebagainya.

Dunia ilmiah sebenarnya belum dapat menjelaskan dengan tepat apa mutisme itu. Oleh karena itu, tak heran bila kita banyak dapatkan teori dan anggapan dari berbagai pihak tentang mutisme. Setiap orang yang tidak dapat berkomunikasi verbal dinyatakan sebagai mutisti, dengan begitu seseorang yang membisu sebagai tindakan protesnonverbal dapat dianggap menderita mutisme histerik, padahal sebenarnya merupakan sindrom konversi histerik. Perwujudan histeria lain adalah mutisme elektif karena membisunya itu ditujukan kepada orang-orang tertentu saja, misalnya kepada gurunya atau pacarnya. Dewasa ini apa yang dulu dikenal sebagai mutisme ainetik lebih dikenal sebagai locked-in sydrome. Dalam hal ini, si penderita masih hidup arena jangtung, paru-paru, ginjal, hati dan hampir semua organ masih berfungsi. Hanya gerakan voluntar, piiran, minat, keinginan dan semua fungsi luhur lainnya sudah tidak bekerja sama sekali. Mutisme lain diketahui penyebabnya, hanya baru diperkirakan mutism ini adalah suatu keadaan jiwa yang terganggu sejak dilahirkan (Sidharta, 1982:76).

Mutisme tidak bisa disamakan dengan orang bisu, apalagi dengan bisu tuli. Dalam hal kebisuan ini sebenarnya perlu dibedakan adanya tiga macam penderita. Pertama, orang yang bisu karena kerusakan atau kelainan alat artiulasi, sehingga dia tidak bisa memproduksi ujaran bahasa, tetapi alat dengarnya normal sehingga dia dapat mendengar. Kedua, orang yang bisu karena kerusakan kelainan alat artikulasi dan alat pendengarnyam sehingga dia tidak bisa memproduksi ujaran bahasa dan juga tidak mendengar ujaran bahasa orang lain. Ketiga, orang bisu yang sebenarnya alat artikulasinya normal tidak ada kelainan, tatapi alat pendengarannya rusak. Orang golongan ketiga ini menjadi bisu karena ia tida pernah mendengar ujaran bahasa orang lain, sehingga dia tidak bisa menirukan ujaran bahasa itu.

Pasien golongan pertama, yang alat artikulasinya rusak atau mengalami kelainan, sedangakan alat pendengarannya normal, masih akan dapat berkomunikasi. Tentunya bila

Jurnal Serambi IImu. p-ISSN 1693-4849, e-ISSN 2549-2306 Journal of Scientific Information and Educational Creativity 
diajak bertutur kata maka dia akan bertanya dalam bahasa isyarat, atau dalam bahasa tulis (jika dia sidah bisa menulis). Psien golongan kedua yang bisu tuli karena alat artikulasi dan alat pendengarannya rusak, sedangkan fungsi hemisfer otak yang dominannya normal, masih akan dapat berkomunikasi dengan bahasa isyarat atau dengan bahasa membaca bibir. Untuk dapat berkomunikasi tentunya memerlukan pendidikan dan pelatihan khusus yang memakan banyak waktu. Pasien golongan ketiga yang menjadi bisu karena kerusakan atau kelainan alat dengarnya, atau fungsi hemisfer otak yang dominannya normal, masih bisa dilatih untuk memproduksi ujaran bahasa secara tidak sempurna karena dia tidak bisa mendengar ujaran bahasa itu. Pelatihan dilakukan dengan cara dia suruh memperhatikannya, memegang dan merasakan gerak mulut melatih berbicara, namun ia tentu memerlukan waktu tang cukup lama.

Gangguan Psikogenetik. Selain karna gangguan faktor mekanisme berbicara sebagaimana dijelaskan di atas, ada juga gangguan berbicara disebabkan oleh mental atau psikogenetik. Gangguan ini bersifat lebih ringan karena lebih tepat disebut dengan variasi cara berbicara yang normal sebagai ungkapan dari gangguan mntal. Modalitas mental ini terungkap dari nada, intonasi, intensitas, suara, lafal dan diksi atau pilihan kata. Ujaran yang berirama lancar atau tersendat-sendat juga dapat mencerminan siap mental. Gangguan psikogenetik ini antara lain seperti berikut.

Berbicara Manja. Disebut berbicara manja karena ada kesan keinginan untuk dimanja sebagaimana anak kecil yang membuat perubahan pada cara bicaranya. Fonem (s) dilafalkan (c) sehingga kalimat "sakit sekali susah sembuhnya" menjadi "cakit cekali cucah cembuhnya". Gejala seperti ini dapat diamati pada orang tua pikun atau jompo (biasanya wanita).

Berbicara Kemayu. Menurut (Chaer, 2007:77) istilah kemayu mengacu pada perangai kewanitaan yang berlebihan yang dalam hal ini ditunjukkan oleh seorang pria. Berbicara kemayu dicirikan oleh gerak bibir dan lidah yang menarik perhatian dan lafal yang dilakukan secara menonjol atau ekstra lemah gemulai dan memanjang. Meskipun berbicara jenis ini tidak langsung termasuk gangguan berbahasa. Tetapi dapat dipandang sebagai sindrom fonologik yang mengungkapkan gangguan identitas kelamin. 
Gagap adalah berbicara kacau kkarena sering tersendat-sendat, mendadak berhenti, lalu mengulang-ngulang suku kata pertama, kata-kata berikutnya, dan setelah berhasil mengucapkan kata-kata itu kalimat dapat berikutnya, dan setelah berhasil mengucapkan kata-kata itu alimat dapat diselesaikan. Seperti orang yang ingin mengatakan "awas ada pohon tumbang”, tetapi ia mengucapkannya secara terputus-putus dan berulang-ulang.

Berbicara latah. Latah adalah respon refleksi berupa perkataan atau perbuatan yang tidak terkendali yang terjadi ketika seseorang merasa kaget. Latah bukanlah penyakit mental, tetapi lebih berupa kebiasaan yang tertanam di pikiran bawah sadar. Setiap orang latah punya respon yang berbeda-beda dalam bereaksi terhadap stimulus yang mengagetkannya, diantaranya: (a) mengulangi perkataan orang lain; (b) meniru gerakan orang lain; (c) mengucapkan kata-kata tertentu berung-ulang (biasanya kata-kata jorok); (d) melaksanaan perintah secara spontan pada saat terkejut, misalnya ketika penderita dikejutkan dengan seruan perintah spontan seperti, "jongkok" atau "loncat", dia akan melaukan perintah itu seketika.

Latah sering disamakan dengan ekolalla, yaitu perubahan membeo, atau menirukan apa yang dikatakan orang lain, tetapi sebenarnya latah adalah suatu sindrom yang terdiri atas curah verbal repetitif yang bersifat jorok (koprolalla) dan gangguan lokomotorik yang dapat dipancing. Koporolalla pada latah ini berorientasi pada alat kelamin laki-laki. Yang sering dihinggapi penyait latah ini adalah orang perempuan berumur 40 tahun ke atas.

\section{METODE PENELITIAN}

Dalam penelitian ini penulis menggunakan pendekatan kualitatif. Menurut Laxy (2004:131) pendekatan kualitatif adalah "data yang dikumpulkan bukan berupa dalam bentuk angka melainkan data tersebut dari naskah wawancara, catatan lapangan dokumentasi pribadi, catatan memo dan dokumen resmi lainnya". Jenis Penelitian deskriptif. Menurut Whithney (dalam Muhamad, 2003:16) bahwa metode deskriptif adalah pencarian fakta dengan interpretasi yang tepat.

Teknik pengumpulan data merupakan cara yang digunakan peneliti untuk mendapatkan data dalam suatu penelitian. Pada penelitian ini, peneliti memilih jenis penelitian kualitatif, maka data yang diperoleh haruslah mendalam, jelas, dan. Menurut

Jurnal Serambi IImu. p-ISSN 1693-4849, e-ISSN 2549-2306 Journal of Scientific Information and Educational Creativity 
Sugiyono (2009: 225) mengemukakan bahwa "pengumpulan dapat diperoleh dari hasil observasi, wawancara,".

Analisis data adalah proses mengorganisasikan dan mengurutkan data kedalam pola, kategori, dan satuan uraian dasar sehingga dapat ditemukan tema dan dapat dirumuskan hipotesis kerja seperti yang disarankan oleh data. Dari rumusan di atas dapat di tarik garis besar bahwa analisis data bermaksud untuk mengorganisasikan data. Data yang terkumpul banyak sekali dan terdiri dari catatan lapangan, komentar peneliti, foto, dokumen berupa laporan, dan sebagainya. Setelah data dari lapangan terkumpul dengan menggunakan metode pengumpulan data di atas, maka peneliti akan mengolah dan menganalisis data tersebut dengan menggunakan analisis secara deskriptif-kualitatif, tanpa menggunakan teknik kuantitatif.

Analisis deskriptif-kualitatif merupakan suatu tehnik yang menggambarkan dan menginterpretasikan arti data-data yang telah terkumpul dengan memberikan perhatian dan merekam sebanyak mungkin aspek situasi yang diteliti pada saat itu, sehingga memperoleh gambaran secara umum dan menyeluruh tentang keadaan sebenarnya. Menurut Nazir (2003:44) bahwa: "tujuan deskriptif ini adalah untuk membuat deskripsi, gambaran atau lukisan secara sistematis, faktual dan akurat mengenai fakta-fakta, sifat-sifat serta hubungan antar fenomena yang diselidiki”.

\section{HASIL PENELITIAN}

Sekolah luar biasa ini berdiri kurang lebih 15 tahun, Selama proses pendirian ini hanya ada beberapa orang anak yang sekolah disini, pada saat itu banyak kendala yang dihadapi, terutama dalam hal biaya. Dengan bantuan dari oknum lain dan pemerintah sekolah ini dapat berdiri sampai sekarang. Gangguan bahasa memang banyak anak-anak yang kami temukan dengan adanya tenaga-tenaga perawat dalam melatih anak untuk berbahasa dan bicara, sehingga anak mulai terbiasa untuk berbahasa

Anak dengan gangguan bahasa ada sekitar 15 orang, yang diantaranya rata-rata berumur di atas 10 tahun, yang memang dominannya bahasa yang dia ucapkan tidak dimengerti oleh orang lain, awalnya saya juga tidak mengerti, kurang memahami, tetapi setelah saya pelajari dan setiap harinya saya berbaur dengan dia, sekarang saya sudah 
mengerti dengan bahasa yang dia katakan, kami disini bukan hanya membiarkan dengan bahasa yang dia katakan, tetapi kami juga membantu agar bahasanya sama dengan anak pada umumnya, berbicara lancar dan benar.

Dengan kesabaran dan tekat yang kuat para perawata di SLB-AB Bukesra berusaha sekuat tenaga untuk bisa mengajarkan anak-anak untuk bisa berbahasa sedikit-demi sedikit walaupun bekerja pasti ada keluhan, ya terutama dalam belajar bersama anak-anak. Dengan anak-anak yang normal aja kita merasa mengeluh, apalagi dengan anak yang tidak normal. Dengan hal ini, dan itu yang dia tidak mau melakukannya, untuk menyuruh menulis saja, itu butuh waktu lama untuk dia mau menulis, dengan berbagai alasan yang kita berikan, dan kemudian mereka melemparkan pertanyaan yang sangat sulit untuk kita jawab.

Anak dengan gangguan berbahasa perlu mendapatkan perhatian dengan menstimulasi dan mengarahkan anak untuk bisa beradaptasi dengan lingkungannya meskipun tidak seutuhnya anak tersebu bisa sembuh.

Untuk gangguan bicara yang lebih banyak disini, rata-rata bisu, yang tidak dapat berbicara. Ada yang bisa berbicara satu sampai 10 kata yang dimengerti oleh orang lain, kadang bisa memanggil papa, mama saja dan beberapa atau lainnya, karena kata tersebut mudah diucapan dan sudah diajar oleh orang tua sejak dia masih bayi. Dan juga ada yang sama sekali tidak dapat berbicara dan juga tidak dapat mendengar, butuh pengasuhan perawatan yang ekstra untuk anak dengan gangguan bicara dan tuli.

Dengan perawatan yang dilakukan oleh perawat, tentunya dengan penuh kesabaran dan kasih sayang, alhamdullah ada perubahan. Dengan anak gangguan bahasa, yang dulunya bahasa nya tida dapat dimengerti oleh orang lain, dengan perlahan kami sudah mengajarkan dengan baik, dan bahasa nya sudah mulai berubah dan dapat dimengerti oleh orang lain. Dengan bahasa mereka yang tidak pas, dan tidak dimengerti, dan kami juga kebingungan dengan bahasa yang dia katakan, tetapi sekarang sudah ada perubahan, bukan hanya itu saja mereka juga di ajarkan membaca, menulis dan berhitung oleh perawat disini.

Dimana-mana bekerja pasti ada keluhan, ya terutama dalam belajar bersama anakanak. Dengan anak-anak yang normal aja kita merasa mengeluh, apalagi dengan anak yang tidak normal. Dengan hal ini, dan itu yang dia tidak mau melakukannya, untuk menyuruh menulis saja, itu butuh waktu lama untuk dia mau menulis, dengan berbagai alasan yang kita berikan, dan kemudian mereka melemparkan pertanyaan yang sangat sulit untuk kita jawab.

Jurnal Serambi IImu. p-ISSN 1693-4849, e-ISSN 2549-2306 
Tentunya ada perubahan, dengan kerja keras dan kasih sayang yang penuh yang kami berikan kepada mereka, ada peubahan juga pada anak dengan gangguan berbicara. Dengan anak yang tidak dapat berbicara atau bisu, dan hanya beberapa kata yang dapat dia ucapkan, sekarang sudah lebih dari kata itu yang dia ucapan, dan kami juga mengajarkan bahasa tubuh, yang dapat dia mengerti dan juga orang lain, sedangan untuk anak yang mengalami bisu dan tuli, kami juga mengajarkan bahasa tubuh, dan utuk ketuliannya kami memasang alat di telinganya, agar dia dapat mendengar walaupun tidak sama seperti orang lainnya. Tentunya untuk anak dengan gangguan bahasa dan bicara ini sangat membutuhkan perhatian yang lebih, agar semganta hidupyang dia miliki tidak jatuh atau drop.

Ya, namanya juga merawat anak dengan gangguan bahasa dan bicara tentunya ada kendala, keluhan, tetapi dibalik semua itu ada hal yang menarik, dengan tingkah lakunya yang lucu dan menggemaskan, dengan hal-hal yang dia lakukan. Keluhan yang kami alami yaitu dalam hal kenakalan dari anak-anak tersebut, ya namnya juga anak-anak pasti bandel atau melakukan hal-hal yang kurang kita sukai, ribut atau sebagainya, itu saja yang membuat kami kewalahan dengan sikap yang dia lakukan.

Namanya juga merawat anak dengan gangguan bahasa dan bicara tentunya pasti ada kendala, keluhan, tetapi dibalik semua itu ada hal yang menarik, dengan tingkah launya yang lucu dan menggemaskan, dengan hal-hal yang dia lakukan. Keluhan yang kami alami yaitu dalam hal kenakalan dari anak-anak tersebut, ya namnya juga anak-anak pasti bandel atau melakukan hal-hal yang kurang kita sukai, ribut atau sebagainya, itu saja yang membuat kami kewalahan dengan sikap yang dia lakukan. Asuhan yang kami berian tentunya sangat berbeda dengan anak-anak normal pada umumnya, untuk anak yang normal dengan kita berbicara memakai bahasa sehari-hari, anak normal dapat mengerti, sedangkan untuk anak dengan gangguan bahasa dan bicara, kita harus mengeja apa yang ingin kita katakan padanya, juga kita harus menggunakan bahasa tubuh, agar ucapan kita dapat dimengerti olehnya, apabila tidak dimengerti juga, kami harus mengeja dan mengulangnya kembali.

Asuhan yang kami berikan tentunya sangat berbeda dengan anak-anak normal pada umumnya, untuk anak yang normal dengan kita berbicara memakai bahasa sehari-hari, anak normal dapat mengerti, sedangkan untuk anak dengan gangguan bahasa dan bicara, kita harus mengeja apa yang ingin kita katakan padanya, juga kita harus menggunakan bahasa 
tubuh, agar ucapan kita dapat dimengerti olehnya, apabila tidak dimengerti juga, kami harus mengeja dan mengulangnya kembali. Yang pasti asuhannya berbeda dengan anak yang normal.

Anak-anak dengan kebutuhan khusus memang perlu mendapatkan perhatian khusus bagi anak tersebut, berbeda dengan anak pada umumnya, anak yang memiliki kebutuhan khusus harus mendapat perhatian khusus bagi anak tersebut dengan stimulasi dan mengajarkan bahasa dan bicara anak-anak akan mulai terbiasa untuk melatih anggota gerak yaitu otot-otot pada mulut untuk bicara dan berbahasa, maka dari itu anak berkebutuhan khusus perlu mendapat perhatian khusus.

Selama proses perawatan, tentunya anak dengan gangguan bahasa dan bicara ini mengalami drop, yang mana dengan kekurangan yang dia miliki dengan keterbatasannya pasti merasa, bahwa dia tidak sama dengan temannya yang lain. Pernah menangis, dan mereka juga mengatakan "kenapa saya seperti ini, Tuhan tidak sayang pada kami”, dan sebagainya. Untuk membuatnya merasa nyaman, dan selalu tidak berfiir kalau apa yang dia alami sekarang itu adalah karena Tuhan sayang padanya, dan nanti akan memasukkannya ke dalam surga tanpa adanya perhitungan dari Tuhan. Ya seperti itu kami selalu memberikan masukan yang positif kepada mereka.

Selama proses perawatan tentunya anak merasa drop, dan merasa bahwa dia tidak sama seperti anakk yang lainnya, mereka merasa Tuhan tidak adil. Banyak anak-anak dengan kekurangan bertanya kepada kami, bahkan sampai menangis dan teriak-teriak. Saya sendiri yang merawatnya sangat merasa sedih, tapi saya terus memberikan perhatian dan semangat yang kuat bahwa Tuhan itu sayang sama dia, dia adalah anak istimewa di mata Allah di banding anak lainnya.

Pendidikan merupakan usaha manusia untuk membina kepribadian sesuai dengan nilai-nilai di masyarakat atau sebagai upaya membantu peserta didik untuk mengembangkan dan meningkatkan pengetahuan, kecakapan, nilai, sikap dan pola tingkah laku yang berguna bagi hidup. Pendidikan adalah memanusiakan manusia muda. Pendidikan bukanlah menghilangkan harkat dan martabat sebagai manusia, melainkan.

Menumbuhkan dan mempertinggi mutu dan hakekat serta martabat manusia. Oleh karena itu pendidikan sifatnya mempengaruhi bukan menghilangkan, sebab tidak ada yang hilang dalam proses pendidikan. Hanya sifatnya mempengaruhi hal-hal yang kurang baik ke

Jurnal Serambi IImu. p-ISSN 1693-4849, e-ISSN 2549-2306 Journal of Scientific Information and Educational Creativity 
arah yang baik dan memperkembangkan potensi yang positif menjadi maksimal sesuai dengan potensinya.

Pendidikan berkaitan dengan transmisi pengetahuan, sikap, kepercayaan, keterampilan dan aspek-aspek kelakuan lainnya, kepada generasi yang lebih muda. Pendidikan merupakan suatu proses pembelajaran pola-pola kelakuan manusia menurut apa yang diharapkan oleh masyarakat. Asalkan pendidikan yang berlaku, harus tetap berpedoman berdasarkan pada Pancasila dan Undang-Undang Dasar Negara Republik Indonesia tahun 1945 yang berakar pada nilai-nilai agama, kebudayaan nasional Indonesia dan tanggap terhadap tuntutan perubahan zaman. Penelitian ini ingin mengkaji tentang pendidikan khusus, mengetahui sejarah pendidikan khusus dan sistem pendidikan dalam pendidikan khusus untuk anak cacat khususnya anak tunanetra.

Sekolah Luar Biasa adalah sebuah lembaga pendidikan formal yang melayani pendidikan bagi anak-anak berkebutuhan khusus. Sebagai lembaga pendidikan SLB dibentuk oleh banyak unsur yang diarahkan untuk mencapai tujuan pendidikan, yang proses intinya adalah pembelajaran bagi peserta didik. Jadi SLB merupakan lembaga pendidikan khusus yang menyelenggarakan program pendidikan bagi anak berkebutuhan khusus.

Dalam ketentuan umum UU Sisdiknas tahun 2003 pasal 1 ayat 1 dikemukakan bahwa: "Proses pembelajaran agar peserta didik secara aktif mengembangkan potensi dirinya, kecerdasan, akhlak mulia, serta keterampilan, yang diperlukan dirinya, masyarakat, bangsa dan Negara" (UU Sisdiknas, 2006:72). Bertitik tolak dari tujuan itulah setiap lembaga pendidikan termasuk di dalamnya Sekolah Luar Biasa hendaknya bergerak dari awal hingga akhir sampai titik tujuan suatu proses pendidikan, yang pada akhirnya dapat "mewujudkan terjadinya pembelajaran sebagai suatu proses aktualisasi potensi peserta didik menjadi kompetensi yang dapat dimanfaatkan atau digunakan dalam kehidupan" (Suderadjat, 2005:6).

Syafaruddin (2002:87) mengemukakan bahwa "Dalam sistem pendidikan nasional Indonesia sekolah memiliki peranan strategis sebagai institusi penyelenggara kegiatan pendidikan." Oleh karena itu, jelaslah bahwa Sekolah Luar Biasa memiliki dan mengemban tugas yang berat tetapi penting. Berat karena harus selalu berperang menghadapi berbagai kelemahan, ancaman dan tantangan guna menselaraskan program-program kegiatan yang 
terealisir dengan dinamika perkembangan ilmu pengetahuan dan teknologi (iptek) yang bergerak demikian cepat. Penting, karena tugas-tugas dan fungsi sekolah sangat diperlukan untuk mengembangkan potensi anak-anak berkebutuhan khusus demi kelangsungan hidupnya yang harus selalu dinamis dan optimis.

Untuk melihat keberhasilan suatu sekolah tentu harus diukur dengan kriteria sebagaimana dikemukakan Sergiovanni dan Carver bahwa ada empat tujuan yaitu: Efektivitas produksi, efisiensi, kemampuan menyesuaikan diri (adaptiveness), dan kepuasan kerja, dapat digunakan sebagai kriteria untuk menentukan keberhasilan suatu penyelenggaraan sekolah. Efektivitas produksi, yang berarti menghasilkan sejumlah lulusan yang sesuai dengan tuntutan kurikulum yang berlaku.

\section{KESIMPULAN}

Berdasarkan pembahasan pada bab-bab sebelumnya, maka dapat ditarik kesimpulan tentang konsep keperawatan anak dengan gangguan bahasa dan bicara yaitu sebagai berikut:

Pada umumnya, untuk anak yang normal dengan kita berbicara memakai bahasa sehari-hari, anak normal dapat mengerti, sedangkan untuk anak dengan gangguan bahasa dan bicara, kita harus mengeja apa yang ingin kita katakan padanya, juga kita harus menggunakan bahasa tubuh, agar ucapan kita dapat dimengerti olehnya, apabila tidak dimengerti juga, kami harus mengeja dan mengulangnya kembali. Yang pasti asuhannya berbeda dengan anak yang normal. Oleh sebab itu pendidikan khusus merupakan salah satu pendekatan penting bagi anak-anak dan masa depan anak.

\section{DAFTAR PUSTAKA}

- Arikunto, S. 2013. Prosedur Penelitian Suatu Pendekatan Praktik. Jakarta: Rineka Cipta.

- Bukhari. 2010. Keterampilan Berbahasa Membaca dan Menulis. Banda Aceh yayasan Pena.

- Chaer,Abdul. 2007. Sosiolinguistik. Jakarta: Rineka Cipta.

- David Werner, 2002. Anak-anak Desa Yang Menyandang Cacat. Malang: Yayasan Bhakti Luhur.

- Hastuti, 2003. Kumpulan cerita dongeng. Bandung.

Jurnal Serambi Ilmu. p-ISSN 1693-4849, e-ISSN 2549-2306 Journal of Scientific Information and Educational Creativity 
- Hidayat, Aziz Alimul. 2005. Pengantar Ilmu Keperawatan Anak, Ed I: Jakarta, Salemba Medika.

- Jack de Groot, 1997. Neuroanatomi Korelatif. Jakarta: EGC.

- Lickona, Thomas. 2013. Education for Character, mendidik untuk membentuk karaker. Jakarta: Bumi Aksara.

- Margono. 2004. Metode Penelitian Pendidikan.Jakarta: Rhineka Cipta.

- Mardalis. 2006. Metode Penelitian Suatu Pendekatan Proposal. Jakarta: Bumi Aksara.

- Moleong, Laxy . 2004. Metode Penelitian Kualitatif. Bandung: Remaja Rosda Karya.

- Muslich, Masnur. 2008. Pendidikan Karakter. Jakarta: Bumi Aksara.

- Nurliza, E.N.E., 2017. Analisis Gaya Bahasa Dalam Cerita Rakyat Aceh Besar. JURNAL SERAMBI ILMU, 29(2).

- Nurgiyantoro, 2005. Sastra anak, Pengantar Pemahaman Dunia Anak. Yogyakarta:Gama Press.

- Nazir, Muhammad 2003. Metode Penelitian. Jakarta: Ghalia Indonesia.

- Rampan. 1986. Sastra Indonesia. Bandung: Alfabeta.

- Sidharta. 1982. Tata Pemeriksaan Klinis dalam Neurologi. Jakarta: Selemba.

- Sugiono. 2010. Metode Penelitian Tindakan Kelas Pendekatan Kuantitatif, Kualitatif, dan R\&D. Bandung: Alfabeta.

- Syafaruddin 2002. Manajemen Mutu Terpadu dalam Pendidikan. Jakarta: Grasindo.

- Taringan. 1991. Dalam (Carolina,2001:18) Pengertian tentang Berbicara. Bandung: Angkasa.

- _ 1984. Menjelaskan tentang Pengertian Berbicara. Bandung: Angkasa.

- 1 1983. Pengertian tentang berbicara. Bandung: Angkasa.

- Widjaja, 2008. Ilmu Komunikasi Pengantar Studi. Jakarta: Rineka Cipta. 